\title{
Impact of Corporate Governance on Environmental Protection Investment of China's Listed Enterprises in High-polluting Industry
}

\author{
Kai Wang
}

Admissions and Employment Service Department, Xinyang Normal University, Xinyang, Henan, 464000, China $\dagger$ Corresponding author: Kai Wang; wangkai19870@163.com

Nat. Env. \& Poll. Tech. Website: www.neptjournal.com

Received: 12-09-2020

Revised: $27-12-2020$

Accepted: 09-01-2021

Key Words:

Listed Enterprises

High-polluting industry

Corporate governance

Panel data

\begin{abstract}
With the rapid development of the economy, people's pursuit of the quality of life is getting higher. Thus, environmental pollution will be punished, and the high-polluting industry will face more problems in development. To explore the impact of corporate governance on environmental protection investment, 28 listed enterprises in high-polluting industry in China were selected as samples. Corporate governance was reflected from four aspects as explaining variables including shareholding structure, board composition, characteristics of the supervisory board and executive incentive. The relationship between corporate governance and high-polluting enterprises' environmental protection investment was analysed by using the data of China's listed enterprises in the high-polluting industry from 2015 to 2019. The results indicate that there is a positive correlation between legal person proportion and environmental protection investment of high-polluting enterprises, and a U-shaped relationship of the Herfindahl index. There is a significant positive correlation between board size and environmental protection investment of high-polluting enterprises, and the relationship is significantly negative of the size of the board of supervisors. The conclusions are helpful to improve the corporate governance of high-polluting enterprises, to enhancing environmental protection investment.
\end{abstract}

\section{INTRODUCTION}

It has become the consensus of all countries in the world to implement the strictest ecological environment protection system. The promulgation of various laws and policies reflected the state's attention to environmental protection and determination to control environmental pollution. The Ministry of Ecology and Environment of China has designated 16 industries, including thermal power, steel, cement, electrolytic aluminium, coal, metallurgy, chemical, petrochemical, building materials, paper making, brewing, pharmaceutical, fermentation, textile, leather and mining, as high-polluting enterprises. According to statistics, there were more than 500 high-polluting enterprises listed in China in these 16 industries. High-polluting enterprises discharged a large amount of waste gas, wastewater, waste residue and noise every year, causing research damage to the surrounding ecological environment. In recent years, on the one hand, the high-polluting industry's investment growth rate has declined and the debt burden has risen. On the other hand, Xi Jinping of Chinese President proposed, "Clearwater and green mountains are golden hills and silver mountains". The high-polluting industry is faced with greater pressure to transform. Therefore, under these circumstances, there is strong theoretical and practical significance not only to study the relationship between listed enterprises' governance and environmental protection investment in the high-polluting industry but also to explore how to enhance environmental protection investment through standardizing corporate governance.

A new round of scientific and technological revolution and industrial change is emerging. Corporate governance and environmental protection investment are hot issues all the time. Environmental protection investment can not only improve the reputation of high-polluting enterprises but also respond to the national call to continuously optimize product structure and achieve technological upgrading. Good corporate governance can ensure high-polluting enterprises to increase environmental protection investment, but scholars have not studied different components of corporate governance affect environmental protection investment. It is necessary for high-polluting industry having an invincible position to reform and innovate in an open market environment. Thus, one of the effective ways is to standardize corporate governance.

\section{PAST STUDIES AND RESEARCH HYPOTHESIS}

\section{Ownership Structure and Environmental Protection Investment}

Relationship between equity nature and environmental protection investment: After the implementation of the reform of listed enterprises in the high-polluting industry, 
equity gradually achieved the "full circulation", state-owned non-tradable shares flow into the capital market (Wang et al. 2009). Corporate and institutional investors' shareholding ratio increased gradually, but this did not necessarily lead to the reduction of state-owned shares. State-owned shares, "only one big share", still existed in the short term. Agency problems and owner absence existed generally for listed companies in the high-polluting industry (Liu et al. 2011). State-owned shareholders chose improper incentives and regulations to managers easily lead to moral hazard problems, and it affected the environmental protection investment, for the reason that low environmental protection investment could help the enterprise gain more profit. Compared to state-owned shares, legal person shares had more "economic person" personality characteristics (Shleifer et al. 1986). The pursuit of them was the long-term and stable return on investment, using "voting by hand" to participate in the decision-making, to achieve the maximization of benefits. Legal person shares had obvious advantages in the supervision of managers. Tradable shares had strong flexibility and the holders were extremely dispersed, which had "take a ride" behaviour. Supervision to the operation and management of listed enterprises in the high-polluting industry was weak, and it was difficult to reach good corporate governance. Based on this, it puts forward the hypothesis:

Hypothesis 1a: there is a negative correlation between the proportion of state-owned shares and environmental protection investment of listed enterprises in the highpolluting industry.

Hypothesis 1b: there is a positive correlation between the proportion of corporate shares and environmental protection investment of listed enterprises in the high-polluting industry.

Hypothesis 1c: there is a positive correlation between the proportion of tradable shares and environmental protection investment of listed enterprises in the high-polluting industry.

Relationship between equity concentration and environmental protection investment: A relatively concentrated ownership structure could encourage shareholders to implement effective supervision, but the expansion of ownership concentration degree would possibly cause violations of the interests of small shareholders from the large shareholders. Listed enterprises in the highpolluting industry most were restructured from state-owned enterprises and as the controlling shareholder, the state was unable to perform the supervision responsibility, which made control eventually transferred to the hands of executives. It formed "insider control". Based on this, it puts forward the hypothesis:

Hypothesis 2a: there is a positive correlation between the proportion of the first shareholder and environmental pro- tection investment of listed enterprises in the high-polluting industry.

Hypothesis 2b: there is an inverted $U$ relationship between Herfindahl index and environmental protection investment of listed enterprises in the high-polluting industry.

Relationship between equity balance degree and environmental protection investment: The theory of information asymmetry showed that large shareholders and small shareholders had different information, which caused the controlling shareholder to grab the interests of other shareholders. Equity balance of listed enterprises in the high-polluting industry could reduce these problems caused by information asymmetry (Azadegan et al. 2019). If the degree of equity balance was higher, then the restriction and supervision function between shareholders was stronger. However, if the equity balance degree was too high, it was easy to cause the decentralization of power. Decision-making efficiency might decrease. Based on this, it puts forward the hypothesis:

Hypothesis 3a: there is a $U$ relationship between $S$ index and environmental protection investment of listed enterprises in the high-polluting industry.

Hypothesis 3b: there is an inverted $U$ relationship between $\mathrm{Z}$ index and environmental protection investment of listed enterprises in the high-polluting industry.

\section{Board of Directors and Environmental Protection Investment}

Relationship between board size and environmental protection investment: Directors of listed enterprises in the high-polluting industry would be operating efficiently under the board of directors of the scale effect, the big number of directors would easily cause members between communication and coordination disorder, leading to the low efficiency of the board of directors (Yermack 1996). The deterioration of the relationship between the board members is due to the competition for power and profit and the shirking of responsibility. It might lead to internal fierce struggle and consumption of resources (Lan et al. 2009). Besides, the larger number of board members easily led to "free rider" motivation. It was more likely to happen when ownership and company operating losses. Based on this, it puts forward the hypothesis:

Hypothesis 4: there is a negative correlation between board size and environmental protection investment of listed enterprises in the high-polluting industry.

Relationship between the proportion of independent directors and environmental protection investment: Independent directors usually did not have shares of listed enterprises in the high-polluting industry, which were not 
directly influenced by the controlling shareholder of the company. The board of directors and executives are conducive a benefit for their independent judgment on the affairs of the company (Jensen et al. 1976). Independent directors were composed of experts in various fields, which could provide a reference for the scientific decision-making of the board of directors with various information and specialized knowledge. The proportion of independent directors on the board of directors was different, which had a great influence on the responsibilities of the board of directors (Qin 2018). Based on this, it puts forward the hypothesis:

Hypothesis 5: there is a positive correlation between the proportion of independent directors and the environmental protection investment of listed enterprises in the high-polluting industry.

\section{Board of Supervisors and Environmental Protection Investment}

As an internal supervision mechanism of listed enterprises in the high-polluting industry, the board of supervisors exercised supervision right on behalf of investors and was responsible for the general meeting of shareholders (Li et al. 2016). Its basic function was responsible for overseeing the company's all business activities and financial status. It could require that the board of directors and executives promptly corrected the ultra vires act in violation of the articles of association of the company, to reduce the probability of making mistakes and financial fraud. Based on this, it puts forward the hypothesis:

Hypothesis 6: there is a positive correlation between the scale of the board of supervisors and the environmental protection investment of listed enterprises in the highpolluting industry.

\section{Executive Incentive and Environmental Protection Investment}

Executives' shareholding ratio of listed enterprises in the high-polluting industry was very low. The long-term incentive effect was not obvious, mainly by salary. Based on the agency theory, when there was information asymmetry between executives and shareholders, the shareholders needed to sign a compensation performance contract with executives, to reduce the agency cost of executives caused by moral hazard and adverse selection (Wu et al. 2019). Then, they could achieve the maximization of their wealth. Based on this, it puts forward the hypothesis:

Hypothesis 7: there is a positive correlation between executive annual salary and environmental protection investment of listed enterprises in the high-polluting industry.

\section{MATERIALS AND METHODS}

\section{Data Source}

This study selected 28 listed enterprises in the high-polluting industry. Sample data was chosen from the CSMAR database, Wind database and annual reports from 2015 to 2019. The information comes from the Shanghai Stock Exchange, the Shenzhen Stock Exchange, and the official websites of enterprises. This study uses an Excel table to process the original data and SPSS19.0 software for processing and analysis.

\section{Modelling}

According to the above hypothesis, this study uses multiple linear regression models to examine the relationship between variables. The specific model is as follows:

$$
y_{i t}=c+\alpha \sum x_{i t}+\beta L n T A_{i t}+\varepsilon_{i t}
$$

Where, $c$ is the intercept, $\alpha$ and $\beta$ are the coefficients of explanatory variables. $\varepsilon_{\text {it }}$ is the error term. $y_{i t}$ is shown as 0 or 1 . It is judged from the information, which can be found in annual reports of the listed enterprises.

\section{Variables}

The proportion of state-owned shares, the proportion of corporate shares and proportion of tradable shares reflect equity nature. The proportion of the first largest shareholder and Herfindahl index reflect equity concentration. $S$ index and $\mathrm{Z}$ index reflect equity balance degree. These variables all belong to the category of equity structure. Board size and the proportion of independent directors reflect board of directors. The scale of the board of supervisors reflects the board of supervisors. Executive annual salary reflects executive incentive. Corporate governance variables are given in Table 1.

\section{RESULTS ANALYSIS}

To eliminate heteroscedasticity, multivariate regression model uses respectively natural logarithm of the executive annual salary and total assets. This study selects variables that the relationships are significant and it uses a fixed effect and random effects panel regression method to analyze. The results are shown in model (1)-(2) in Table 2. Then it adds other variables regression and only presents the results by Hausman test such as the model (3)-(5). Finally, this study makes the global variable into the regression model and the results are shown in the model (6)-(7). The $D W$ values of the model (1), (3)-(6) are 2.43, 2.46, 2.37, 2.43 and 2.40, which declare that multivariate regression model does not have a serial correlation. Thus, $R^{2}$ is greater than 0.56 and it has greatly improved. $F$ value is all through the significant test. 
Table 1: Corporate governance variable definition.

\begin{tabular}{|c|c|c|c|c|}
\hline \multicolumn{2}{|c|}{ Variable properties } & \multirow{2}{*}{$\begin{array}{l}\text { Variable names } \\
\text { Proportion of state-owned shares }\end{array}$} & \multirow{2}{*}{$\begin{array}{l}\text { Variable symbol } \\
\text { GYG }\end{array}$} & \multirow{2}{*}{$\begin{array}{l}\text { Variable interpretation } \\
\text { State-owned shares/Total share capital }\end{array}$} \\
\hline Own- & Equity nature & & & \\
\hline structure & & Proportion of corporate shares & FRG & Legal person shares/Total share capital \\
\hline & & Proportion of Tradable shares & LTG & Negotiable shares /Total share capital \\
\hline & \multirow[t]{2}{*}{$\begin{array}{l}\text { Equity } \\
\text { concentration }\end{array}$} & $\begin{array}{l}\text { Proportion of the first largest share- } \\
\text { holder }\end{array}$ & CR1 & $\begin{array}{l}\text { The first major shareholders holdings /Total share } \\
\text { capital }\end{array}$ \\
\hline & & Herfindahl index & $\mathrm{H} 10$ & $\begin{array}{l}\text { Sum of squares of Share ratio of the top ten } \\
\text { shareholders }\end{array}$ \\
\hline & \multirow[t]{2}{*}{$\begin{array}{l}\text { Equity } \\
\text { balance degree }\end{array}$} & S index & $\mathrm{S}$ & $\begin{array}{l}\text { The sum of Second shareholders to the tenth largest } \\
\text { shareholder ratio }\end{array}$ \\
\hline & & $\mathrm{Z}$ index & $\mathrm{Z}$ & $\begin{array}{l}\text { The proportion of the first largest shareholder/Sec- } \\
\text { ond share ratio of major shareholders }\end{array}$ \\
\hline \multirow{2}{*}{\multicolumn{2}{|c|}{ Board of directors }} & Board size & DSS & Total number of board of directors \\
\hline & & Proportion of independent directors & DDR & $\begin{array}{l}\text { Number of independent directors/Total number of } \\
\text { board of directors }\end{array}$ \\
\hline \multicolumn{2}{|c|}{ Board of supervisors } & The scale of the board of supervisors & JSS & The total number of the board of supervisors \\
\hline \multicolumn{2}{|c|}{ Executive incentive } & Executive annual salary & GGS & Average annual salary of the top three executives \\
\hline
\end{tabular}

In model (1) and (3), the proportion of corporate shares is positively related to environmental protection investment at $1 \%$ significant level. The proportion of state-owned shares and proportion of tradable shares harm environmental protection investment, but the results are not significant, shown as model (3)-(6). In the model (1), (3)-(7), the proportion of the first largest shareholder has a significant negative impact on environmental protection investment, but the regression result does not support the expectation hypothesis. With the acceleration of the state-owned enterprises' reforming, state-owned shares of listed enterprises in the high-polluting industry gradually realize the market circulation. Nevertheless, in most cases, state-owned share as the largest shareholder remains unchanged. The problem of supervision absence resulting from the lack of major shareholders is serious, as well as insider control. However, large numbers of small shareholders are scattered in the circulation stocks, which results in a widely existing phenomenon of "getting a lift" and weakening of supervision to management. To maximize their interests, legal person shareholders with the characteristics of "economic man" will actively participate in corporate decision-making, supervise the management and promote corporate governance mechanism to work. Therefore, hypothesis $1 \mathrm{~b}$ is proved and the others are not proved.

At $10 \%$ significant level, Herfindahl index is positively related to environmental protection investment, while its square term shows the opposite direction and the result is not significant. But, the results of single-variable regression show that environmental protection investment decreases with the increase of Herfindahl index. When Herfindahl index is among 0 0.388, the environmental protection investment increases with Herfindahl index. When Herfindahl index is among $0.388 \sim 1$, the environmental protection investment decreases. Therefore, hypothesis $2 \mathrm{~b}$ is proved.

The failure of impacts of $S$ and $Z$ index on environmental protection investment reflects the weak force of ownership balance of listed enterprises in the high-polluting industry. Therefore, hypothesis $3 \mathrm{~b}$ and $3 \mathrm{a}$ are both not proved.

In model (1), (3) and (4), board size is negatively related to the environmental protection investment significantly at the $10 \%$ level. The generally larger companies easily cause dysfunction, difficulties in communication and low efficiency of decision-making. In practice, the number of the board of directors has average more than 8 people in 23 listed enterprises in the high-polluting industry in 2019. Boards with big size cannot play a good role in supervisory and easily cause low efficiency of decision-making. The regression results are consistent with the theoretical expectations, so hypothesis 4 is proved.

In $t$ model (5) and (6), the proportion of independent directors has a positive impact on environmental protection investment, which is consistent with theoretical expectations. The result is not significant. According to the theory of corporate governance, independent directors only receiving allowances, considered as external supervision of the company, can generate constraints on business activities and improve the financial situation of the enterprise; the 
Table 2: Multivariable panel data regression results.

\begin{tabular}{|c|c|c|c|c|c|c|c|}
\hline \multirow[t]{2}{*}{ (Model) } & \multicolumn{2}{|c|}{ Main variable regression } & \multicolumn{3}{|c|}{ Added other explanation variables regression } & \multicolumn{2}{|c|}{ All explanatory variables regression } \\
\hline & (1) & (2) & (3) & (4) & (5) & (6) & (7) \\
\hline Regression method & Fixed Effect & Random Effect & Fixed Effect & Fixed Effect & Fixed Effect & Fixed Effect & Random Effect \\
\hline $\mathrm{C}$ & $8.33 * * *$ & 0.75 & $8.63 * * *$ & $9.74 * * *$ & 9.12 & 8.61 & -2.99 \\
\hline LnTA & $-0.34 * * *$ & $-0.21 * * *$ & $-0.48 * * *$ & $-0.43 * * *$ & $-0.35 * * *$ & $-0.33 * * *$ & $-0.16 * * *$ \\
\hline GYG & - & - & -0.20 & -0.90 & -0.89 & -1.00 & 2.27 \\
\hline FRG & $1.89 * * *$ & 0.36 & $1.83 * * *$ & 1.11 & 1.14 & 1.12 & 2.69 \\
\hline LTG & - & - & - & -0.78 & -0.70 & -0.89 & 2.37 \\
\hline CR1 & $-10.32 * *$ & 0.70 & $-11.17 * *$ & $-11.23 * *$ & $-10.42 *$ & $-11.81 *$ & 2.47 \\
\hline S & -0.74 & $1.32 *$ & -0.54 & -0.48 & -0.33 & 2.13 & 1.37 \\
\hline S2 & - & - & - & - & - & -237 & 1.58 \\
\hline H10 & $13.31 *$ & 0.68 & $13.76 *$ & $14.36 *$ & $14.31 *$ & $14.32 *$ & -1.51 \\
\hline H102 & -4.15 & -0.33 & -4.84 & -5.67 & -5.78 & -621 & 1.04 \\
\hline Z & - & - & - & - & - & 0.01 & 0.01 \\
\hline $\mathrm{Z} 2$ & - & - & - & - & - & 0.01 & 0.01 \\
\hline DSS & $-0.11 *$ & -0.09 & $-0.10 *$ & $-0.10 *$ & -0.068 & -0.07 & -0.03 \\
\hline DDR & - & - & - & - & 1.65 & 1.66 & $2.78 * *$ \\
\hline JSS & $-0.22 * * *$ & 0.10 & $-0.23 * * *$ & $-0.25 * * *$ & $-0.23 * * *$ & $-0.24 * * *$ & 0.04 \\
\hline LnGSS & 0.12 & $0.18 *$ & 0.21 & 0.23 & 0.19 & 0.12 & $0.17 *$ \\
\hline $\mathrm{R}^{2}$ & 0.57 & 0.12 & 0.57 & 0.57 & 0.65 & 0.58 & 0.15 \\
\hline F-statistic & $3.42 * * *$ & $2.10 *$ & $3.76 * * *$ & $3.68 * * *$ & $3.51 * * *$ & $3.23 * * *$ & 1.51 \\
\hline DW value & 2.43 & 1.65 & 2.46 & 2.37 & 2.43 & 2.40 & 1.89 \\
\hline Hausman & $38.11 * * *$ & - & $38.44 * * *$ & $39.51 * * *$ & $40.32 * * *$ & $41.39 * *$ & - \\
\hline
\end{tabular}

Note: $* * *, * *$, * denote parameter estimates are significant at the level of $1 \%, 5 \%, 10 \%$, models of (3)-(5) are tested by Hausman to determine which one is more suitable.

proportion of independent directors of listed enterprises in the high-polluting industry is $1 / 3$ about the baseline. This is the main reason why the regression result is not significant. Therefore, hypothesis 5 is proved.

The influence of the board of supervisors on the environmental protection investment is significantly negative at the $1 \%$ level. A significant level of the board of supervisors on the negative impact of environmental protection investment has been improved after introducing other variables. Yang (2013) proposed to evaluate whether the board of supervisors had achieved the goal of effective supervision from the guarantee of ability and operation effectiveness. Board of supervisors should reach a certain scale to ensure the effectiveness of the operation. The member of supervisors of listed enterprises in the high-polluting industry all meet the specified requirements, but most of them also work for other companies or receive compensation from related entities, leading to the failure of the supervisory function. This not only wastes the enterprise's resources but also reduces the enterprise's operating efficiency. The regression results do not support the theory anticipated. So, hypothesis 6 is not proved.
The results show that the natural logarithm of executive annual salary on environmental protection investment is significantly positive at the $15 \%$ level. In the high-polluting industry, the annual salary of executives has a significant incentive effect on management. Moreover, the growth trend of the average annual salary of senior executives in the industry has proved the hypothesis well. So, hypothesis 7 is proved.

\section{CONCLUSIONS}

The impact of corporate governance on environmental protection investment of high-polluting enterprises is explored by using the data of 28 listed enterprises in high-polluting industry in China from 2015 to 2019. The conclusions are drawn as follows. (1) The proportion of corporate shares has a significant positive effect on the environmental protection investment, which means highpolluting enterprises may implement more actions that are conducive to environmental governance and environmental protection investment enhancement. (2) Herfindahl index and environmental protection investment have a significant 
U-shaped relationship. More small and medium-sized shareholders may make good decisions for high-polluting enterprises, which can reduce environmental pollution and increase social identity. (3) A significant negative correlation is found between the board size and environmental protection investment. With the enlargement of the board size, the decision-making efficiency of the board of directors will drop, which will lead to environmental protection investment decline of listed enterprises in the high-polluting industry. (4) The scale of the board of supervisors and environmental protection investment show a significant negative correlation. With the enlargement of the board of supervisors' size, the environmental protection investment of listed enterprises in the high-polluting industry will be worse. Many supervisors may be unable to perform an effective supervisory function, leading to high-polluting enterprises carrying out environmentally harmful behaviours. (5) Executive annual salary has a significant positive effect on the environmental protection investment. Raising the annual salary of senior executives can help improve environmental protection investment of listed enterprises in the high-polluting industry. As a high polluter not only creates social environmental protection investment but also causes serious damage to the surrounding environment. High-polluting enterprises should attach great importance to environmental protection by strengthening corporate governance.

\section{REFERENCES}

Azadegan, A., Golara, S., Kach, A. and Mousavi, N. 2018. Corporate environmental investments: a cross-national study on managerial decision making. International Journal of Production Economics, 5(199): 47-64.

Jensen, M.C. and William, H.M. 1976. Theory of the firm: Managerial behavior, agency costs and ownership structure. Journal of Financial Economics, 3: 305-360.

Lan, Y.J. and Xu, D.L. 2009. The empirical study of listed corporate board governance and value of China's commercial chain enterprises. Comparative Economic and Social Systems, 27(1): 171-175.

Li, W.A. and Chen, H. 2016. The empirical study on the governance evaluation of the board of supervisors in China's listed enterprises. Shanghai University of Finance and Economics, 38(3): 78-84.

Liu, Y.Y., Huang, Z., Xie, D.X. and He, X.F. 2011. The empirical study of Chinese listed companies ownership structure and environmental protection investment. Economic and Management Research, 37(2): 24-32.

Qin, S.S. 2018. An empirical analysis of relationship between characteristics of the board of supervisors and enterpries' performance. Journal of Capital University of Economics and Business, 3: 51-55.

Shleifer, A. and Vishny, R. 1986. Large shareholders and corporate control. Journal of Political Economy, 94: 461-488.

Wang, X.H. and Xu, J. 2009. Ownership structure, capital structure and environmental protection investment of different growth opportunities - taking a distribution industry listed companies. Business Economics and Management, 7(3): 20-28.

Wu, Y.H. and Wu, S.N. 2019. Executive compensation: incentives or selfinterest: the evidence from China's listed enterprises. Accounting Research, 11: 40-48+96-97.

Yang, D. 2013. Corporate governance and performance of enterprise - based on sociological analyses of Chinese experience. Chinese Social Science, 33(1): 72-94.

Yermack, D. 1996. Higher market valuation of companies with a small board of directors. Journal of Financial Economics, 40(2): 185-211. 